Abdelrehim N, Toms S. The obsolescing bargain model and Oil: The AngloIranian Oil Company 1933-1951. Business History 2017, 59(4), 554-571.

DOI link

https://doi.org/10.1080/00076791.2016.1232397

ePrints link

http://eprint.ncl.ac.uk/pub details2.aspx?pub id=243510

Date deposited

$06 / 12 / 2017$

Embargo release date

$23 / 03 / 2018$

Copyright

This is an Accepted Manuscript of an article published by Taylor \& Francis in Business History on $23 / 09 / 2017$, available online:

http://www.tandfonline.com/10.1080/00076791.2016.1232397 


\title{
The obsolescing bargain model and oil: the Anglo-Iranian Oil Company 1933-1951
}

\author{
Neveen Abdelrehim ${ }^{\mathrm{a}, \mathrm{b}}$ and Steven Toms ${ }^{\mathrm{c}}$
}

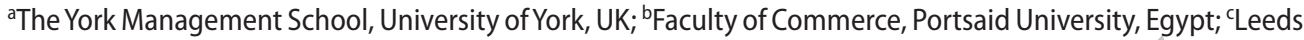
University Business School,University of Leeds, UK

\section{ABSTRACT}

We employ archival evidence to investigate events culminating in the nationalisation of the Anglo-Iranian Oil Company (AIOC) in 1951, which followed disagreements over profit allocations arising from a previously negotiated concession. The case study expands the traditional obsolescing bargain model (OBM) by accommodating the use and impact of accounting information in negotiation contexts. The analysis reveals that managerial control and the deployment of accounting information by the AIOC temporarily strengthened its bargaining power vis-à-vis the Iranian government leading up to the nationalisation crisis, demonstrating the potential importance of these new dimensions in wider contexts.

\section{KEYWORDS}

Obsolescing bargain modelling (OBM); Iranian oil industry; Anglo-Iranian Oil Company (AIOC); accounting

\section{Introduction}

In May 1951, following protracted negotiations and a resulting crisis, the Iranian government nationalised the local assets of the Anglo-Iranian Oil Company (AIOC). Many studies of similar expropriations have used the obsolescing bargaining model (OBM) to explain power shifts between the multinational enterprise (MNE) and host country $(\mathrm{HC})$ government. ${ }^{1}$ In the model, the bargaining power of the MNE, however favourable the terms of entry, is undermined, or rendered obsolete, once sunk investments are made in the HC. Since the wave of oil and natural resource expropriations of the mid-twentieth century, MNEs have recently gained more bargaining power through the greater willingness of $\mathrm{HC}$ governments to co-operate, for example via international institutions and trade organisations, which has led to the development of new models. These can be described as political bargaining models (PBM), of which the OBM is a specific case. ${ }^{2}$ In PBM models, emphasis is placed on the ability of the MNE to use political process and resource control to obviate the tendency to obsolescence.

In this article, we suggest two further extensions of the PBM/OBM approach. These are first, the roles of managerial control and accounting information. In MNE/HC bargaining situations, relative power is a function of staff deployments, particularly in roles demanding specialist knowledge. Whether overseas technical specialists appointed and trained by the MNE are used, or alternatively, locally recruited experts, can potentially govern the balance 
of power between the MNE and HC. Likewise, how accounting information is produced and disclosed, most usually at the behest of the senior management of the MNE, can strongly influence the bargaining position. The second extension is to place the model in a dynamic and iterative context, such that entry conditions and early phase outcomes influence subsequent outcomes, and there are discontinuities or tipping points, meaning that the MNE's bargaining position can obsolesce suddenly.

Using this approach illustrates the value of historical analysis in relation to the general international business literature, and provides an important justification for analysing the AIOC case. Although the case is well known, and has been examined from a number of perspectives, ${ }^{3}$ it can potentially shed new light on the relationships implied by the OBM and its variants as outlined above. Moreover, by examining the role of accounting in the dynamic bargaining process, new evidence not hitherto examined in the business history or accounting literatures can be employed. In such fashion, the role of accounting in diplomatic contexts, or in bargaining situations between the MNE and HC, upon which the business history, accounting and wider literatures are currently silent, can be better understood.

These gaps in the literature lead us to our principal research questions, summarised as follows. First, how did bargaining gains split between the parties and how did they reflect and in turn impact on their bargaining strategies? Second, did the AIOC use management control and accounting information to impact dynamically on the iterative negotiations leading up to the nationalisation crisis? Third, to what extent is the extension of the PBM/ OBM to include these dimensions warranted in the general case? Archival evidence, including new sources, is utilised in order to better answer these questions.

The remainder of the article is structured as follows. The next section reviews the literature on MNE/HC bargaining focusing on the OBM approach, leading to a conceptual framework extending the OBM to include management control, accounting information, and dynamic interactions. The third section discusses the research methodology and the framing of the Iranian nationalisation case study. In the fourth section, empirical evidence is introduced, examining the motivations of the main protagonists and how accounting was used in a series of bargaining situations. The conclusion summarises the main arguments.

\section{Bargaining models}

The OBM is frequently referred to as the accepted paradigm of MNE-HC government relations in international political economy. ${ }^{4}$ In detail, the OBM explains the changing nature of bargaining relations between an MNE and $\mathrm{HC}$ government as a function of the goals, resources and constraints of both parties. ${ }^{5}$ Gains for each party depend on relative bargaining power, determined by ability to withhold resources and capabilities, such as raw materials, capital, and technological and access to rare country-specific advantages, such as valuable mineral resources. ${ }^{6}$ The outcome should favour the party with the strongest resources, highest issue salience, weakest constraints and greatest coercive power. ${ }^{7}$ Relative bargaining power shifts to the $\mathrm{HC}$ government over time as the MNE transfers assets to the $\mathrm{HC}$ in the form of sunk investments, causing the original bargain to obsolesce. Some scholars argue that the OBM has outlived its usefulness, as $\mathrm{HC}$ governments have since become more co-operative towards MNE investors. ${ }^{8}$ Case studies that have tested the model reveal that MNEs often retain relative bargaining power and prevent $\mathrm{HC}$ governments from behaving opportunistically so that bargains, in practice, are seldom obsolesced. ${ }^{9}$ 
Recognising these apparent weaknesses in the original OBM, certain modifications have been suggested. These have included the argument that MNE-HC relations are iterative political bargains negotiated between MNEs and HC governments over firm and country specific resources, together with a variety of government policies at the industry level, influenced by, and linked to, alliances, interests and behaviour outside the specific issue at stake. The outcomes can be also influenced by governance inseparability, where previously agreed contracts are irreversible. ${ }^{10}$ Political aspects of MNE strategic behaviour, designed to generate firm-specific advantage based on improved relationships with governments include resource commitment, personal relations, lobbying and political accommodation. ${ }^{11}$ Where the outcome appears to favour the MNE in terms of distribution of gains, for example where the investment turns out to be more profitable than the original negotiations envisaged, the $\mathrm{HC}$ government's perception of the benefit cost ratio may fall, potentially causing the bargain to obsolesce. ${ }^{12}$ The MNE's use of accounting mechanisms to disguise the profitability of its operations is therefore of substantial potential significance.

Whilst acknowledging the value of general extensions to the OBM in the form of the PBM, it is noteworthy that they do not specifically accommodate the roles of managerial control of assets and the accounting function. Likewise, the accounting literature, when considering colonial contexts has not considered the allocations of gains from MNE investments, nor the role of accounting in potentially distorting the profitability of such projects, concentrating more broadly on the role of profit and profit maximisation as a motive force of subordination in colonial contexts. ${ }^{13}$ Where managerial control and accounting are used in bargaining, the situation naturally evolves iteratively, demonstrating the value of the business history approach. Business historians have applied dynamic approaches to similar cases of MNE-HC bargaining accompanied by the threat of expropriation, for example US MNEs Kaisers in Ghana and the United Fruit Company in Latin America. ${ }^{14}$ This article builds on these dynamic approaches by incorporating management control and accounting dimensions and integrating them with the key facets of the OBM/PBM. Such an approach allows us to integrate the above literature review with our additional perspectives in the form of a conceptual framework through which MNE-HC government bargaining dynamics can be examined.

The framework is illustrated in Figure 1. Initial entry conditions set the framework for the relative bargaining power of the two sides. As in the OBM, the $\mathrm{HC}$ bargaining position is strengthened as the MNE makes sunk investments. The relative positions of both sides are mediated by $\mathrm{HC}$ public policies that apply to industry specific issues, such as local regulation and access to markets, along with associated legitimation strategies by the MNE. For convenience, these factors are labelled as PBM bargaining enhancement factors in Figure 1. These dimensions are borrowed from the OBM and PBM perspectives, as outlined above. Further dimensions, specified in Figure 1 are the MNE's systems of management control and the production of accounting information. These dimensions are closely linked. Assets owned by the MNE, and their control by its managers, provide an important opportunity for corporate executives to use subjective decisions on valuation and information disclosure, whether in diplomatic contexts or through its financial reporting function, to bolster their bargaining position. Bargaining enhancement factors can reflect conflictual and co-operative motives in the bargaining process and the outcomes are reflected in the relative distribution of gains. Insofar as these accrue to the $\mathrm{HC}$, the traditional OBM applies, and insofar as they accrue to the MNE, the incremental factors arising from the PBM, management control and accounting are dominant and obsolescence is mitigated. The relative gains are further mediated by 


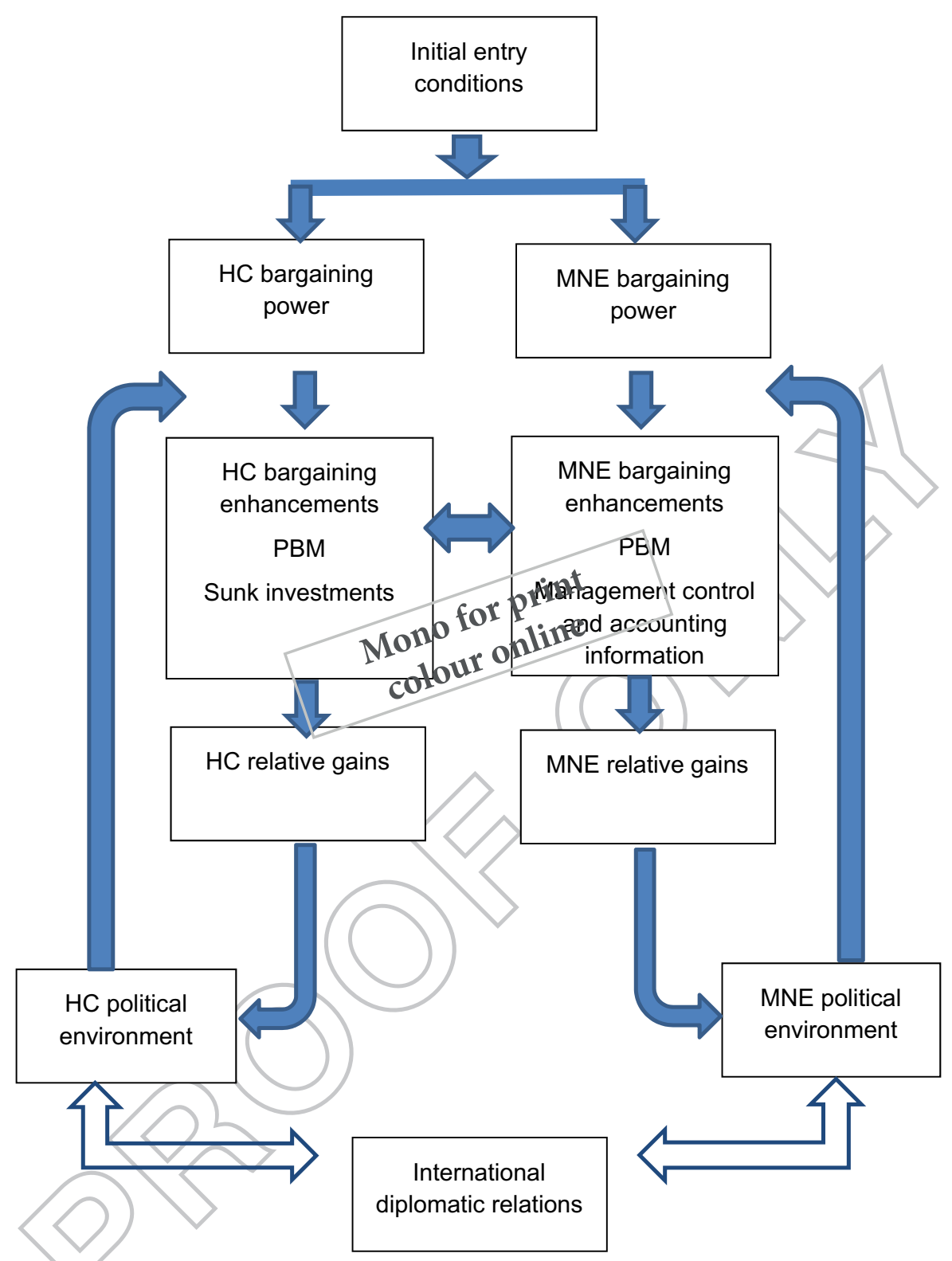

Figure 1. An extended bargaining model.

political environments, which for the $\mathrm{HC}$ include the attitudes of stakeholder groups, including employees, political parties and lobbies, and, for the MNE, include domestic shareholders and involvement with wider industry networks. The environments of both are linked through the operation of international diplomacy and participation in international and multi-lateral organisations. Accrual of gains from either side then, interacts positively and negatively with these environments, which determine the revised bargaining position of the participants in the next round of negotiations. A final noteworthy feature of Figure 1, connecting the MNE-HC political environments, is the indirect emphasis attributed to geo-political and 
diplomatic interactions, which can be substantial and complex, so that whilst the model has its primary focus of the dyadic nature of MNE-HC relations, it acknowledges such additional influences as the aggregate of other powerful stakeholders. The relationships in Figure 1 accommodate dynamic iterations, and for the purposes of presentational simplicity show the bargaining opportunities and gains to be in symmetry. In reality, the balance of bargaining power and distribution of gains can tip in favour of one side or the other. As a consequence, new bargaining strategies can emerge, if the gains are unbalanced, potentially also leading to rapid obsolescence of the checks and balances implied in the model.

The advantages of the conceptual framework are that it provides an overview of the main relationships suggested by the literature, with the addition of the new dimensions suggested from the above review. These relationships can now be examined further by considering empirical evidence. The next section outlines the rationale for choosing the AIOC case study, and the specific focus of attention, as a means of further elaborating the conceptual framework.

\section{Methodology and case study background}

The case study examines the relationship between the AIOC and successive Iranian governments in the period 1933-1951. The reason for the selection of these dates is that 1951 was the year in which the Iranian government nationalised the local assets of the AIOC. In broad terms, the expropriation marked the obsolescence of the agreement made in 1933, which set the tone of the subsequent negotiations up to the crisis of 1951.

As noted above, important novel dimensions are managerial control and the role of accounting information. The AIOC case is particularly useful in this respect, because from the outset, deployment of technical staff and profit and profit sharing were at the centre of MNE-HC negotiations and concessions. These issues were established from the outset, when the original concession, negotiated by William Knox D'Arcy, led to the discovery of significant new oil field and the construction of a refinery at Abadan. The Anglo Persian Oil Company (the predecessor of the AIOC) was then established with the exclusive right to explore, develop, exploit, and transport petroleum in return for providing the Iranian government with $16 \%$ of the net profit on all operations. ${ }^{15}$ Subsequent negotiations led to the revision of this allocation, so that in 1933, a new agreement set the royalty paid to Iran at a fixed sum of 4 shillings ( $£ 0.20$ ) per ton, plus $20 \%$ of the dividend payable to ordinary shareholders, and a minimum annual payment of $£ 750,000$, whilst local assets would be shifted to Iranian management through the employment of local staff in technical roles (referred to as 'Iranianisation'). ${ }^{16}$ As with accounting profit, Iranianisation provided AIOC executives with significant scope for voluntary action, reporting and interpretation. ${ }^{17}$

The problematic nature of profit determination and distribution between the MNE and $\mathrm{HC}$ has been noted in the literature. For example, Mansoor argues that, by the AIOC's own admission, accurately calculating profits was complex, ${ }^{18}$ while Elm believes the British government manipulated dividends and taxes so that 'Iran was left at the mercy of the British government, which by increasing AIOC's taxes decreased the company's net profits and thus decreased Iran's 20\% share in dividends and general reserves.' ${ }^{19}$ Keddie agrees, noting that the AIOC paid much more in income tax to the British government than it did in royalties to the Iranian government. ${ }^{20}$ Similar conflicts over profit and profit sharing arose with the second most important British business institution in Iran, the Imperial Bank, which was 
accused of disguising its profits by making transfers to or from 'inner' or 'secret' reserves before reaching the published figure. The Imperial Bank's'real' profits were, on average, about twice as high as its published profits between 1890 and $1952 .{ }^{21}$

Although these prior studies acknowledge that accounting was at the centre of negotiations in a number of contexts in Iran over a long period, there has been no systematic analysis of profit distribution or how profits were reported by the AIOC. To fill this gap therefore, using the BP Archive at Coventry, the article first introduces new evidence drawn from the annual reports of the AIOC in the period 1933 to $1950 .{ }^{22}$ Second, the article uses further archival evidence in the form of memoranda and correspondence that sheds further light on how these accounting numbers were interpreted. The same evidence also facilitates our analysis of the exercise of management control, of which the use of accounting was an important component. Of particular significance in all these respects is the Gidel memorandum. In 1948, to assist its renegotiation of the 1933 concession, the Iranian government appointed Gilbert Gidel, a French Law Professor from the University of Paris. The crucial role of the memorandum was acknowledged in the literature, ${ }^{23}$ but its contents have not thus far been empirically analysed in detail. Gidel's focus was on the accounting, governance and legal aspects of the agreement, and the contents of his memorandum are therefore of particular importance for our investigation below. ${ }^{24}$

\section{AIOC/British and Iranian government bargaining, 1933-1951}

20 This new evidence is now used to develop a case study focused on the use of accounting in the bargaining process between the AIOC and Iranian government over oil concessions and their renegotiation in the period from 1933 to the nationalisation crisis of the first half of 1951. The evidence is used to address each of the research questions in turn. The first section below therefore discusses evidence on how the gains were distributed in the bargaining process. Having contextualised the process, the role of accounting information in negotiations with specific reference to the main points of contention, which centred on profit, profit distribution, and taxation is explained in the next section. The conclusion section following the case analysis includes a discussion of the generalisability of the model in Figure 1 with reference to the empirical findings.

\section{Profits and profit sharing, 1933-1951}

As noted earlier, an important ingredient of the OBM approach is the distribution of gains between the MNE and HC government. Such splits can depend on the initial entry conditions but also the evolution of relative bargaining strength of the parties. To examine the empirical trend so that the evolution of the bargaining process can be contextualised, the split of profits between the main claimants, the Iranian government, the British government and residual AIOC non-Iranian shareholders, is analysed in Table 1.

The figures in Table 1 are calculated from the AIOC Annual Report and Accounts (19331950). The distribution of profits between major claimants is shown in $£ 000$ s and as percentages of the total for each year. The distribution of profits reflects the terms of the 1933 agreement and the (51\%) stake in the equity of the AIOC taken by the British government. Residual, non-Iranian AIOC shareholders thus had a $49 \%$ stake in the equity and also controlled the preference shares. ${ }^{25}$ All parties' shares therefore depended on production levels, 
Table 1. AIOC profit distribution, 1933-1950.

\begin{tabular}{|c|c|c|c|c|c|c|c|}
\hline \multirow[b]{2}{*}{ Year } & \multicolumn{2}{|c|}{ Iranian Government* } & \multicolumn{2}{|c|}{ British Government** } & \multicolumn{2}{|c|}{ AIOC shareholders** } & \multirow{2}{*}{$\frac{\text { AIOC profits }}{£ 000 \mathrm{~s}}$} \\
\hline & $£ 000 \mathrm{~s}$ & $\%$ & $£ 000$ s & $\%$ & $£ 000 \mathrm{~s}$ & $\%$ & \\
\hline 1933 & 1,785 & 22.29 & 2,781 & 34.73 & 3,442 & 42.98 & 8,007 \\
\hline 1934 & 2,159 & 25.22 & 2,978 & 34.79 & 3,423 & 39.99 & 8,560 \\
\hline 1935 & 2,192 & 25.79 & 2,899 & 34.10 & 3,409 & 40.11 & 8,500 \\
\hline 1936 & 2,580 & 30.08 & 2,967 & 34.59 & 3,031 & 35.33 & 8,577 \\
\hline 1937 & 3,545 & 31.17 & 4,240 & 37.28 & 3,589 & 31.55 & 11,374 \\
\hline 1938 & 3,307 & 34.55 & 3,214 & 33.58 & 3,050 & 31.87 & 9,571 \\
\hline 1939 & 2,771 & 40.54 & 2,457 & 35.94 & 1,608 & 23.53 & 6,836 \\
\hline 1940 & 2,786 & 37.35 & 3,204 & 42.95 & 1,469 & 19.70 & 7,459 \\
\hline 1941 & 2,025 & 27.61 & 3,548 & 48.38 & 1,760 & 24.01 & 7,334 \\
\hline 1942 & 3,428 & 25.40 & 6,886 & 51.03 & 3,181 & 23.57 & 13,494 \\
\hline 1943 & 3,618 & 31.56 & 4,770 & 41.60 & 3,078 & 26.84 & 11,465 \\
\hline 1944 & 4,460 & 36.01 & 4,779 & 38.74 & 3,128 & 25.25 & 12,387 \\
\hline 1945 & 5,620 & 40.76 & 4,954 & 35.92 & 3,216 & 23.32 & 13,789 \\
\hline 1946 & 7,130 & 37.32 & 6,974 & 36.51 & 4,999 & 26.17 & 19,103 \\
\hline 1947 & 7,101 & 19.08 & 21,527 & 57.85 & 8,581 & 23.06 & 37,210 \\
\hline 1948 & 9,175 & 16.65 & 35,013 & 63.56 & 10,907 & 19.80 & 55,090 \\
\hline 1949 & 13,489 & 27.77 & 26,945 & 55.47 & 8,146 & & 48,580 \\
\hline 1950 & 16,032 & 19.18 & 53,902 & 64.47 & 13,671 & & 83,605 \\
\hline
\end{tabular}

Notes: *Iranian government share consists of production royalties plus $20 \%$ of the ordinary dividend in excess of $£ 671 \mathrm{k}$. ${ }^{* *}$ Residual profits divided 51:49 between British Government, and other non AIOC Shareholders. ${ }^{* *}$ AIOC profits are adjusted by adding back Iranian production royalties already deducted as a production cost in arriving at the disclosed profit per the report and accounts.

Sources: AIOC annual report, 1933-1950.

but the distribution of gains between them also depended on oil prices, as the Iranian government received a fixed royalty per ton, and on the dividend policy of the AIOC executives; in other words, their decisions about whether to pay a high proportion of profits to shareholders as dividends, or to retain those profits as reserves.

As the trends in Table 1 show, the distribution of gains varied considerably through time. In the years immediately following the new concession in 1933, the Iranian government typically received less than $30 \%$ of profits. The high demand for oil during the post-war reconstruction of Europe enabled the company to achieve a rapid expansion in the volume of its sales and profits. These rose from $£ 7.3$ million in 1941 to $£ 48.5$ million in 1949 before more than doubling to approximately $£ 83.6$ million in 1950 . Although the profits of the AIOC demonstrated a generally rising trend up to 1950, the gains were distributed unevenly. Indeed, in percentage terms, the Iranian government share rose during years of lower profit, as it received a relatively fixed proportion of a variable overall profit. The fixed price royalty and reliance on dividend distributions limited the percentage share falling to the Iranians to historically low levels after 1945. A further factor at work here was the much higher share accruing directly to the British government at the expense of both the Iranian government and residual AIOC shareholders. The new distribution can be explained by increases in taxes on profits levied by the British government during the post-1945 period.

At first sight, the post 1945 distribution of gains in Figure 1 is the opposite of the predictions of the OBM. In the pure OBM model, the gains to the MNE should decline at the expense of the $\mathrm{HC}$ as sunk investments increase. To assess the extent to which this was actually the case, Table 2 analyses the AIOC's capital expenditure in the post-war period. As Table 2 shows, the AIOC invested a substantial proportion of its funds, the majority of which came from profitable operations in new fixed capital projects. However, as Table 2 also shows, the majority of these funds were invested outside Iran, and the proportion tended to increase further 
Table 2. Funds generated and location of capital expenditure: 1946-1951.

\begin{tabular}{|c|c|c|c|c|c|}
\hline & $A$ & B & C & $\mathrm{D}$ & $E$ \\
\hline & $\begin{array}{l}\text { Funds generated } \\
\text { from operations }\end{array}$ & $\begin{array}{l}\text { Increase in long } \\
\text { term capital* }\end{array}$ & $\begin{array}{l}\text { Capital Expenditure } \\
\text { (total) }\end{array}$ & $\begin{array}{l}\text { Capital Expenditure } \\
\text { (Iran) }\end{array}$ & $\% \mathrm{D} / \mathrm{C}$ \\
\hline 1946 & 15.2 & Nil & 20.2 & 9.0 & 44.55 \\
\hline 1947 & 43.9 & $\mathrm{Nil}$ & 31.0 & 8.0 & 25.81 \\
\hline 1948 & 58.8 & Nil & 39.0 & 14.0 & 35.90 \\
\hline 1949 & 43.1 & 1.6 & 55.7 & 18.0 & 32.32 \\
\hline 1950 & 93.5 & 0.8 & 42.1 & 10.0 & 23.75 \\
\hline 1951 & 83.2 & 4.2 & 60.2 & $\mathrm{n} / \mathrm{a}$ & $\mathrm{n} / \mathrm{a}$ \\
\hline Totals & 337.7 & 6.6 & 188.0 & $59^{* *}$ & $31.38^{* *}$ \\
\hline
\end{tabular}

Notes: *Refers to long-term loan capital only as there were no equity share issues; ${ }^{* *}$ Excludes 1951, the year of the nationalisation crisis.

Sources: Adapted from Bamberg, The History of the British Petroleum Company, Table 10.4, 276 and Figure 14.1, 348.

after 1946. In OBM terms, although the AIOC had substantial fixed investments in Iran, they did not increase substantially relative to investments elsewhere, suggesting that the company's strategy was to reduce its dependence on Iran. In 1946, 94.62\% of the AIOC's activity was in Iran, reflecting typical pre-war levels, but by 1950 this had fallen to $80.15 \%$, with rapid increases in activity in Kuwait, Iraq and the UK. ${ }^{26}$ Furthermore, an apparent reluctance to carry through commitments on Iranianisation left British technical staff with substantial influence over the deployment and operation of assets in Iran. In summary, the pattern of fixed capital investment was unlikely to erode the AIOC's bargaining power.

Taken together, the data in Tables 1 and 2 suggest a potential strengthening of the AIOC bargaining position. The revealed trends in the data provide important contextual background for analysing the negotiations between the AIOC and successive Iranian governments in the lead up to the nationalisation crisis. Unsurprisingly, the main variables in the tables, relating to capital expenditure royalties, dividend payments, and taxation were the subject of contentious negotiations. These are analysed further in the next section.

\section{The concession bargaining process}

An important reason for the 1933 renegotiation was that the Iranian government mistrusted the process of profit calculation that in turn determined its $16 \%$ share. The fixed royalty per ton and share in the dividend agreed in the 1933 concession were designed to overcome these objections, basing the Iranian share on parameters that were less subject to accounting manipulation. ${ }^{27}$ For the analysis that follows and with reference to Figure 1, the 1933 concession forms the entry conditions for the next phase of the model. As the trends in the previous section suggest, the relatively fixed nature of the entry conditions meant the Iranian government did not participate equally once it was clear that profits would be larger than originally expected. In the eyes of the Iranian government, the bargain was obsolete and pressures to renegotiate mounted once again. In October 1947, the Iranian government passed a bill to initiate a renegotiation of the concession, seeking an increase in royalties and faster progress on Iranianisation.

The new measure reflected PBM elements that potentially strengthened the Iranian government. Secular nationalist sentiments gained ground after 1945, leading to a strong political backlash against British involvement in Iranian, mostly directed against the two leading businesses, the $\mathrm{AIOC}$ and the Imperial Bank. ${ }^{28}$ The leading nationalist politician, $\mathrm{Dr}$ 
Mohammed Musaddiq, used his increasing power base in the Iranian parliament to promote laws that potentially weakened the AIOC. The law of 2 December 1944, for example, prevented the Iranian government from granting concessions to foreigners without the full agreement of parliament. ${ }^{29}$ The 1947 Bill also gave the Iranian government the right to take all necessary measures to secure Iran's rights to her national resources where such rights had been violated. ${ }^{30}$ As Prime Minister in 1951, Musaddiq promulgated the law nationalising the AIOC's assets in Iran. Musaddiq's increasing political power base had been bolstered, at the expense of political groupings and institutions more inclined to compromise, by the distribution of relative gains in favour of the AIOC. These two factors, which might have led to rapid obsolescence of the 1933 concession, explain the AIOC's rapid diversification through its capital investment programme in the period 1946-1950.

In the face of rising nationalism, the AIOC's bargaining position was strengthened through its powerful political connections. These arose from its strategic importance to Britain's national economy and overseas interests. ${ }^{31}$ Effectively, 'the company was mainly owned by the British government, its power was in the end that of Britain.32 Describing the AIOC in 1959, Winston Churchill praised the historical role of 'this great enterprise' and its contribution to 'national prosperity in peace and our safety in war'.33 In Iran, the AIOC was so dominant 'that it was effectively a state within a state and regarded to all intents and purposes as an arm of the British Admiralty and the British strategic policy.' ${ }^{4}$ In geo-political terms, the British government used the AIOC as an instrument of foreign policy to fight communism and advance the Anglo-American special relationship. ${ }^{35}$ At the same time, Iranian oil supplies were 'a major source of soft currency generation and tax revenue for the British government. ${ }^{36}$ The Abadan oil refinery was the largest in the world and'a source of national pride..37 From a bargaining point of view, the AlOC was enormously strengthened by its control of the oil tanker fleet, which could effectively deny any export revenues to Iran. ${ }^{38}$ In view of these resource and policy based advantages, the British government had a strong incentive to ensure that the key elements of the Iranian concessions remained in place.

Nonetheless, they recognised that nationalisation was a real threat. Most officials in the Foreign Office were of the opinion that it would be impossible to work the oilfields without the support of the Iranians, especially if relationships became hostile. ${ }^{39}$ As Herbert Morrison, Leader of the House of Commons and Foreign Secretary, reflected at the height of the nationalisation crisis, if the Iranian oil supplies ceased to flow from Iran 'the consequences upon the economy, the life, and the political and strategic future of wide areas throughout the world would be disastrous since about a quarter of oil products that AIOC draw comes from Abadan'40 For these reasons, the AIOC faced pressure to address the Iranian government's concerns rather than allow them to escalate into more serious grievances. ${ }^{41}$

These political incentives and connections formally strengthened the bargaining position of the AIOC on the one hand, but on the other, impacted on the bargaining response of the Iranian nationalists. They believed with some justification that the AIOC was acting on instructions from British government to effectively deprive the Iranian government of its reasonable share of revenues. ${ }^{42}$ As a consequence, both sides enlisted other PBM elements in this phase of the negotiations, which were manifested in the form of disputes about corporate governance within the framework of local and international law. Notwithstanding the appointment of Gidel, a leading international lawyer, on the Iranian side, most of the advantages in these respects accrued to the AIOC through its strong connections with the British political establishment. 
The Iranian government's lack of trust in the policies and processes followed by the AIOC was the precursor for the issuance of the Gidel Memorandum (hereafter 'the Memorandum'. Gidel summarised the Iranian concerns, to which the AIOC provided a point-by-point response. ${ }^{43}$ The Iranian government was firmly of the belief that their negligible share of the oil profits was the result of AIOC's unnecessary expenditure on activities and goods that were designed to satisfy certain influential people as opposed to genuinely being used for public welfare. ${ }^{44}$ The Iranian case in the Memorandum was thus based on a claim that profits earned in Iran were being invested elsewhere by the AIOC, and that Iran would thus be deprived of its share of profits from these operations. In addition, the Memorandum noted that the company had denied Iranian requests to inspect its books for the purposes of ascertaining the accuracy of royalty and other payments. The Memorandum also pointed out that the AIOC had not improved the working conditions of the Iranian workforce and that foreign personnel had not been reduced in line with agreements. ${ }^{45}$

Meanwhile, in response to the Iranian instigated negotiations, the AIOC now enlisted new elements, including the use of managerial control and financial reporting to bolster its position. Neville Gass, Managing Director of AIOC and the AIOC negotiator in 1939, noted that his Iranian counterparts 'possessed only a very elementary idea of accounts. ${ }^{\prime 6}$ Gass's successor, AIOC Chairman Sir William Fraser, ${ }^{47}$ and his management team, therefore believed themselves to be in a good position to use their control of assets and cash flows and associated accounting arguments as a tool to defend their position against the Iranian government's claims. These claims are now set out in detail, by order of substantive point, referring to the Memorandum's bargaining demand in the first instance and then to the AIOC's response.

Concerning the definition of profit and the /ranian share of these profits, the Memorandum called for the method of calculation of the company's various reserves to be clarified in an accurate manner. ${ }^{48}$ The memorandum also claimed that the AIOC's depreciation calculations unfairly reduced profits and, therefore, the amount of money paid to the Iranian government. ${ }^{49}$ It pointed out that the Iranian government would, in effect, have paid toward the depreciation of properties outside Iran to which it had no legal ownership at the end of the concession. In addition, it suggested that the government would also have paid toward the depreciation of the company's properties in Iran and that these assets should revert to the government at the end of the concession free of any cost. However, the AIOC's intention was that the ordinary stockholders would benefit from the reserves at the end of the concession and from the company's property outside Iran, while the government would have no reversionary right to the property inside Iran. ${ }^{50}$

For the Iranians, the lack of control over profit determination and distribution was made worse by the AIOC's methods of appropriating profits to reserves. Ali Mansur, ${ }^{51}$ a negotiator on the Iranian side, commented that the profits and reserves were implausibly large and advised that ownership rights associated with them should be clarified so that the interests of Iran were completely safeguarded. ${ }^{52}$ He stated that the:

... AIOC has acted under instructions from the British government and reserved terrific amounts in order not to pay more than what the company laid down in the 1933 agreement. However, it should be stipulated in the supplemental agreement that the Iranian government would share in all the reserves up to $20 \%$ whether visible or invisible..$^{53}$ 
In other words, the Iranians were anxious to specify their share in terms of all profits, whether distributed as dividends or not and regardless of how undistributed profits were specified in the company's reserves.

The AIOC negotiators took a different view. They argued that the only amount available to the Iranian government was $20 \%$ of the company's general reserve at the date of expiration of the concession or of its surrender. ${ }^{54}$ To justify the deduction of depreciation on all assets, including those outside Iran, in arriving at the profits in which the Iranian government was entitled to participate, the AIOC noted that overseas assets amounted to less than $1 \%$ of the total gross value. ${ }^{55}$ Other reserves, such as those for taxation, contingencies and deferred repairs, bad debts, stores stock, etc. could not be calculated 'with absolute accuracy' and were not likely to be payable to shareholders unless they were found to have been overstated. ${ }^{56}$ The AIOC position, and the share of profit immediately available to the Iranians, therefore depended significantly on the validity of estimates made by its managers about contingent expenses. Application of the accounting prudence principle, under whichliabilities must be accrued when foreseen, provided a strong financial reporting based defence of the AIOC position. The foreseeability of the expenses in question was entirely a matter of the subjective judgement of AIOC managers, who were free if they chose, to make generous estimates of likely costs, thereby forcing the Iranian government to defer its share of profits.

The bargaining strategy might have succeeded had the Iranian side been sufficiently induced to trust the accounting judgements of AIOC managers. However, such trust was in increasingly short supply. The demand in the Memorandum that the AIOC should open its books for government inspection ${ }^{57}$ hinted at Iranian officials' perception of the questionable nature of the accounting policies and their associated lack of trust in the judgement of AIOC managers. In short, the AIOC refused the demand for inspection citing the apparent objectivity of the basis of payments to the Iranian government and commercial expediency. Considering the AIOC case for refusal in more detail however, it is apparent that these arguments were merely a smokescreen. The Memorandum based the requirement for inspection on the subjectivity of managerial accounting decisions, to which the AIOC responded that the amount distributed as profit by way of dividend was an objective and indisputable measure. ${ }^{58}$ Notwithstanding the literal truth of this statement, the actual amount of the dividend was of course a subjective matter entirely under the control of AIOC management. Moreover, the more those managers chose to limit the proportion of profit paid as a dividend, the greater the amount credited to reserves, and greater the scope for them to manipulate those reserves using accounting estimates. As far as inspecting the books was concerned, therefore, simply asserting that the requirement was obviated by the apparent objectivity of the Iranian share was irrelevant. In putting up this smokescreen, the AIOC was refusing to countenance the bargaining point raised on the Iranian side about reversion of assets at the end of the concession.

As the evidence in Table 1 suggests, the share of profit attributable to the British government rose rapidly after 1945 as a function of changes to taxation rates. The Iranian government percentage share was reduced in equal proportion. The Memorandum's substantive claims were that British tax should not have been deducted from the Iranian government's profit share, and that the AIOC underpaid Iranian tax on its profits because of the immunities it enjoyed. The Memorandum also requested the restoration of its share of profits lost historically due to these arrangements. To support the case, Gidel constructed a table 
Table 3. Taxes paid by the AIOC to the British and Iranian governments.

\begin{tabular}{lcc}
\hline & \multicolumn{2}{c}{ Total tax payable } \\
\cline { 2 - 3 } Year & British government $(£)$ & Iranian Government $(£)$ \\
\hline 1933 & 305,418 & 274,412 \\
1934 & 511,733 & 301,135 \\
1935 & 408,635 & 291,169 \\
1936 & 910,559 & 328,524 \\
1937 & $1,651,588$ & 362,734 \\
1938 & $1,157,029$ & 378,494 \\
1939 & $1,955,606$ & 466,204 \\
1940 & $2,975,156$ & 460,118 \\
1941 & $2,920,682$ & 568,667 \\
1942 & $4,917,486$ & 454,168 \\
1943 & $7,662,764$ & 606,948 \\
1944 & $10,636,457$ & 514,725 \\
1945 & $10,681,364$ & 646,644 \\
1946 & $10,279,241$ & 768,599 \\
1947 & $15,266,665$ & 765,405 \\
\hline
\end{tabular}

Note: From 1943, the British government tax receipts included normal income tax and also excess profit tax. Source: BP 101099, Gidel Memorandum, 1946-1949, 6b.

comparing taxes paid to both the British and the Iranian government from 1933 to 1947 inclusive, reproduced here as Table 3.

As the data in Table 3 show, both governments experienced increases in taxation receipts during the period of the 1933 concession. Amounts paid to the two governments were approximately equal at the outset, but between 1933 and 1947 the Iranian share increased by a factor of 2.79, whilst the British government's share increased by a factor of 50.01 . The increase of the British government share was most pronounced after 1943 when income tax was supplemented by excess profit tax. 59 Gidel argued that without immunities from local customs duties and taxes, the amount received by the Iranian government would have

10 around $£ 17$ million in $1947,,^{60}$ and commensurate therefore with the increases that had gone to the British government.

A further aspect of British fiscal policy that was particularly relevant to the concessionary discussions was the limitation of company dividends. In 1945 the British government called first for voluntary restraints on dividends and subsequently introduced differential profit 15 taxes with higher rates on dividends and lower rates on retentions. ${ }^{61}$ These policies reflected domestic political pressures in a period of wage restraint, and also supply side policies aimed at encouraging investment in the British economy. However, due to the nature of the 1933 concession, these policies also limited the Iranian profit share. The AIOC therefore came under Iranian pressure to increase the dividend, but the company received direct instructions from the British Chancellor of the Exchequer not to do so. As a consequence, although profits rose rapidly, for the three years after 1947, the AIOC dividend payment remained unchanged. ${ }^{62}$

The discrepancy between the sums paid to the British government and Iranian governments unsurprisingly led to Iranian pressures for re-negotiation from a number of quarters, within and outside the government. ${ }^{63}$ Abol Hassan Ebtehaj, Governor of Bank Melli, argued for a fairer distribution in favour of Iran. ${ }^{64}$ Mansur argued that the AIOC enjoyed a range of privileges from their operation in Iran such as cheap labour, exemption from customs duties and charges, exemption from income tax, and freedom to import and export as it liked. He added that the negligible share of revenue received in return was shocking to Iranian public opinion..$^{65}$ The Iranian government claimed the payment structure reflected that the AIOC 
was simply 'the British Government under another form'.66 It was certainly the case, as the data in Tables 1 and 3 suggest, that the British government, through the collection of such taxes, heavily skewed the gains from the concession away from Iran reflecting the AIOC/ British government joint control of assets and financial claims upon them.

Nonetheless, it suited the AIOC to claim a separation of its own interests from the British government for negotiating purposes. The company argued that British tax provisions were beyond its control, and British taxes were a matter for the British government. Furthermore, the AIOC argued that the Iranian government enjoyed benefits from investments that would have been impossible if the company had not been given tax immunity. The AIOC also claimed that the taxes represented revenues that would have been unavailable without the company's investments, as oil reserves would otherwise have not been discovered and developed. ${ }^{67}$ The company's negotiating stance in its response to these specific points also reflected the more general expectation of AIOC executives that Iranians should be grateful for its investments. ${ }^{68}$

In terms of the OBM, it is noteworthy that as $\mathrm{AIOC}$ sunk investments increased, the Iranian gains from the bargain reduced, substantially as a function of tax arrangements. Co-operative actions by the $\mathrm{HC}$ government, along the lines of the PBM modification likewise strengthened the bargaining position of the AIOC. As the discussion above makes clear, managerial control of assets and how they were accounted for, strongly underpinned the bargaining power of the AIOC. As a consequence, the accounting and governance-based arguments assembled in the Memorandum cut little ice with the AIOC negotiators.

However, the dynamic nature of the bargaining process meant that as the AIOC strengthened its position using accounting arguments, the Iranian side was now strongly pressured by the absence of a way forward on the basis of international law. The outcome of the negotiations did nothing to assuage public opinion. The unfairness of the distribution of gains, and lack of recourse through international legal institutions, had been made more transparent by the negotiation process, notwithstanding the attempted obfuscations of the AIOC. As the evidence in Tables 1-3 show, without the need to raise significant new capital, the profits of the AIOC were large and used increasingly to divert funds to new investment 30 opportunities outside Iran.

In relation to the OBM conceptual framework described at the outset of this paper, the evidence illustrates the role of accounting in mitigating bargain obsolescence. Managerial control over assets and accounting policies strongly bolstered the bargaining position of the AIOC. These mechanisms were closely integrated with the fiscal and national and international institutions, all of which underpinned the accounting arguments and further strengthened the AIOC position. The consequent distribution of gains, already strongly favouring the AIOC, was maintained and added to through further iterations of the bargaining process.

The corresponding lack of recourse to conventional bargaining channels on the Iranian side was compounded by the radical transformation of Iranian politics. The large gains appropriated and the very strength of the AIOC's negotiating position in defending these gains now provoked the nationalisation of its Iranian assets. On the 1st of May 1951, the Iranian nationalist Prime Minister, Mohammed Musaddiq, introduced the nationalisation bill 'For the happiness and prosperity of the Iranian nation. ${ }^{69}$ Consequently, British technicians abandoned Iran, and Britain declared a worldwide embargo on Iranian oil, dramatically reducing 
oil production. Iranian assets were frozen in British currency, and exports prohibited. As the crisis unfolded, British business in Iran diminished to a single firm of contractors. ${ }^{70}$

\section{Conclusion}

Using important archival sources and financial analysis of annual reports, the AIOC-Iran case has provided empirical evidence in support of a reformulation of OBM/PBM type models. The modified model integrates key contributions from existing scholarship on MNE-HC bargaining while also demonstrating that these generic bargaining power models can be extended through the inclusion of accounting as a variable, which the management of the MNE controls in parallel with sunk asset investments. Accounting can mitigate the obsolescence normally associated with the build-up of such investments over the period of a concession.

In the AIOC-Iran case, management controlled accounting policies relating to depreciation, treatment of reserves, profit distribution and retention and the effects of taxation were used effectively as bargaining counters. Iranian claims concerning the inequitable consequences of these policies were no doubt justified, as the distribution of gains revealed, and AIOC responses were mere smokescreens. However, the proprietorial nature of accounting information, underpinned by international law and institutions, rendered it non-contestable from the Iranian point of view.

Such non-contestability effectively closed down conventional diplomatic channels for the renegotiation of the 1933 concession, sparking its rapid obsolescence via a political revolt against the AIOC in 1951. The case thereby illustrates the value of analysing the iterative and dynamic nature of these OBM/PBM models using a historical approach. In the AIOC-Iran case, obsolescence was sudden and was a function of the absence of balance in bargaining channels and skewed distribution of gains away from the $\mathrm{HC}$ in favour of the MNE.

This article makes an important contribution to business history and studies on the OBM by highlighting the pivotal role that the accounting methods played in the on-going negotiations between the AIOC and the Iranian government. Furthermore, this research emphasises the role of accounting in bargaining and negotiation situations and how it can reinforce unequal power relations in colonial and similar international post-colonial contexts where a dominant MNE aims to exploit local resources.

The dynamic role of accounting was clear in the AIOC case, suggesting its possible importance in the more general case. Research using OBM/PBM models, whether applied in historical or present day contexts, should therefore at least consider it as a potentially influential factor. To assess the wider significance, however, further research is required. More empirical evidence on how MNEs use their accounts to exercise control over local populations, their resources and their governments can potentially inform a wide range of historical and current debates on the evolution and effectiveness of global institutions of governance.

\section{Notes}

1. Initially developed by Vernon, Sovereignty at Bay; for a recent overview of oil industry bargaining research, see Vivoda, "Resource Nationalism."

2. Eden, Lenway and Schuler "From the Obsolescing." 
3. For example, political economic perspectives: Elm, Oil, Power, and Principle; business history perspectives: Bostock and Jones, British Business in Iran; Bamberg, The History; Chandler, Scale and Scope, 298-304; the effects of the nationalisation crisis on market value: Abdelrehim, Maltby and Toms "Accounting for Power"; the role of corporate social responsibility: Abdelrehim, Maltby and Toms, "Corporate Social Responsibility."

4. Kobrin, "Diffusion as an Explanation"; Nebus and Rufin, "Extending the Bargaining."

5. Brewer, "An Issue Area Approach"; Farge and Wells, "Bargaining Power"; Kobrin, "Diffusion as an Explanation"; Vachani, "Enhancing the Obsolescing."

6. Levy and Prakash, "BargainsOold and New."

7. Vernon, "The Obsolescing Bargain"; Kobrin, "Diffusion as an Explanation"; Brewer, "An Issue Area Approach."

8. Eden et al., From the Obsolescing Bargain.

9. Kobrin, "Testing the Bargaining"; Bennett and Sharpe, "Agenda Setting."

10. Eden et al., "From the Obsolescing Bargain"; Vivoda, "Bargaining Model," 24.

11. Boddewyn, "Political Aspects."

12. Eden et al., "From the Obsolescing Bargain."

13. For example; Neu and Heincke, "The Subaltern Speaks"; Maltby and Tsamenyi, "Narrative Accounting Disclosure."

14. Decker, "Corporate Political Activity"; Bucheli, "Multinational Corporations."

15. Sampson, The Seven Sisters, 53, 122; Issawi and Yeganeh, The Economics, 26; Penrose, The Large International, 109.

16. Esfahani and Pesaran, "Iranian Economy"; Yergin, The Prize, 271; Bostock and Jones, "British Business in Iran," 47; Abdelrehim et al., "Accounting for Power."

17. Abdelrehim et al., "Accounting for Power."

18. Mansoor, "State-centered Vs. Class-centered," 13-14.

19. Elm, Oil, Power and Principle, 37.

20. Keddie, Modern Iran, 124.

21. Jones, "The Imperial Bank."

22. BP, ARC, AIOC Report of directors and balance sheets, 1933-1950.

23. Ansari, Modern Iran; Bamberg, The History; Elm, Oil, Power, and Principle, 53.

24. BP. 101099, Memorandum: Gidel Memorandum; AIOC Response.

25. Bostock and Jones, "British Business in Iran," 36; Chandler, Scale and Scope.

26. Calculated from BP. ARC AIOC Report of directors and balance sheets, 1946 and 1950.

27. BP. 101099, Gidel Memorandum; AIOC Response.

28. Bostock and Jones, "British Business in Iran," 71.

29. Kuniholm, Origins of the Cold War, 201.

30. Ebrahimi, The British Role, 6-7.

31. Marsh, "Anglo-American Crude Diplomacy."

32. Bill and Louis, Musaddiq, 329-330.

33. Onslow, "Battle Lines for Suez."

34. Marsh, "Anglo-American Crude Diplomacy," 28.

35. Marsh, "HMG, AIOC," 143.

36. Marsh, "Anglo-American Crude Diplomacy," 28.

37. Marsh, "The United States," 9.

38. Elm, Oil, Power, and Principle, 119.

39. Sampson, The Seven Sisters, 119.

40. House of Commons, Parliamentary debates 21 June 1951, 747.

41. BP. 126407, Report on visit to Tehran 31 August to 26 October 1948, 5.

42. Ferrier, "The Anglo Iranian Oil Dispute."

43. BP. 101099, Gidel memorandum; AIOC Response.

44. BP. 071181 , Press extracts No. 798 on 6 September 1948, 1.

45. BP. 101099, Gidel memorandum

46. Bamberg, The History, 392. 
47. Fraser took over as Chairman from Lord Cadman in 1941 and retired from the post in 1956. Times, 'Lord Strathalmond', 2 April, 1970.

48. BP. 101099, Gidel memorandum, 6.

49. Because depreciation is an estimated allocation of cost to several accounting periods, and a matter of accounting policy, there is considerable scope for it to be used to manipulate profit.

50. BP. 126422, Note of first meeting of the understanding committee on 1st May 1949, p. 9.

51. Ali Mansur, Iranian Politician. Governor-General of Khurasan and then Azerbaijan. Head of Seven-Year Plan Organisation. Iranian Prime Minister between March and June 1950. Yapp, British Documents, 103.

52. BP. 126422, Note of first meeting of the understanding committee on 1st May 1949, p. 9.

53. BP. 126343, Notes on Supplemental Agreement handed by Ali Mansur to Shepherd on $3^{\text {rd }}$ June 1950, 1.

54. BP. 101099, Gidel memorandum, AIOC response, 30.

55. BP. 72188 , Royalty questionnaire and answers, 9.

56. BP. 101099, memorandum, AIOC response, point (24).

57. BP. 101099, Gidel memorandum, 2.

58. BP. 101099, Gidel Memorandum and AIOC response, point (6).

59. Introduced under the Finance Act 1940 EPT Provisions. Bayley and Miles, The Excess Profits Tax.

60. BP. 101099, Gidel Memorandum, AIOC response, point (17).

20 61. Daunton, Just taxes, 200-201.

62. Bamberg, British Petroleum, 41.

63. BP. 070266, Jacks to Fraser on 19 August 1934, 1.

64. BP. 126407, Report on visit to Tehran 31 August to 26 October 1948, 19.

65. BP. 126343, Notes on Supplemental Agreement handed by Ali Mansur to Shepherd on 3 June $1950,1$.

66. BP. 72017, Memorandum by Admiral Sir Edmond Slade, 23 May 1922, 3.

67. BP. 101099, Gidel memorandum, AIOC response, point (2).

68. Johnson, British Multinationals.

69. House of Commons. Parliamentary debates 1 May 1951.

70. Bostock and Jones, "British Business in Iran," 71.

\section{Disclosure statement}

No potential conflict of interest was reported by the author.

\section{Notes on contributors}

Neveen Abdelrehim's research interests cover the role of accountability, corporate social responsibility, and accounting disclosure from a historical perspective. Her work examines managerial disclosure and the performance of oil companies during nationalisation and independence. Her research has been published in Business History, Enterprise and Society, Accounting History, EDAMBA journal and Critical Perspectives in Accounting journal.

Steven Toms is Professor of Accounting at Leeds University Business School, University of Leeds.

\section{References}

Abdelrehim, Neveen, Josephine Maltby, and Steven Toms. "Accounting for Power and Control: The Anglo-Iranian Oil Nationalization of 1951." Critical Perspectives on Accounting 23, no. 7-8 (2012): 595-607.

Abdelrehim, Neveen, Josephine Maltby, and Steven Toms. "Corporate Social Responsibility and Corporate Control: The Anglo-Iranian Oil Company, 1933-1951." Enterprise and Society 12, no. 4 (2011): 824-862. 
Ansari, Ali. Modern Iran since 1921. London: Longman, 2003.

Bamberg, James. The History of the British Petroleum Company: Vol. 2, The Anglo-Iranian Years 1928-1954. Cambridge: Cambridge University Press, 1994.

Bamberg, James. British Petroleum and Global Oil 1950-1975. The Challenge of Nationalism. Cambridge: Cambridge University Press, 2000.

Bayley, Victor, and Miles Taylor. The Excess Profits Tax. London: Textbooks Ltd, 1940.

Bennett, Douglas, and Kenneth Sharpe. 1979. "Agenda Setting and Bargaining Power: The Mexican State Versus Transnational Automobile Corporations." World Politics 32, no. 1 (1979): 57-89.

Bill, James, and Roger Louis. Musaddiq, Iranian Nationalism, and Oil. Austin, TX: University of Texas Press, 1988.

Boddewyn, Jean. "Political Aspects of MNE Theory." Journal of International Business Studies 19, no. 3 (1988): 341-363.

Bostock, Frances, and Geoffrey Jones. "British Business in Iran, 1860s-1970s." In British Business in Asia since 1860, edited by R Davenport-Hines and G Jones, 31-67. Cambridge: Cambridge University Press, 1989.

BP (British Petroleum) Archive, University of Warwick, Coventry. 070266, Jacks to Fraser on 19 August 1934, 1.

BP. 071181, Press extracts No. 798 on 6 September 1948.

BP. 101099, Memorandum: Gidel Memorandum; AIOC Response.

BP. 126343, Notes on Supplemental Agreement handed by Ali Mansur to Shepherd on 3 June 1950.

BP. 126407, Report on visit to Tehran 31 August to 26 October 1948.

BP. 126422, Note of first meeting of the understanding committee on 1 May 1949,

BP. 72017, Memorandum by Admiral Sir Edmond Slade, 23 May 1922.

BP. ARC, AIOC Report of directors and balance sheets, 1933-1950.

Brewer, Thomas. "An Issue Area Approach to the Analysis of MNE-government Relations." Journal of International Business Studies 23, no. 2 (1992):295-309.

Bucheli, Marcelo."Multinational Corporations, Totalitarian Regimes and Economic Nationalism: United Fruit Company in Central America, 1899-1975," Business History 50, no. 4 (2008): 433-454.

Chandler, Alfred. Scale and Scope: The Dynamics of Industrial Capitalism. Cambridge, MA: The Belknap Press, 1990.

Decker, Stephanie. “Corporate Political Activity in Less Developed Countries: The Volta River Project in Ghana, 1958-66." Business History 53, no. 7 (2011): 993-1017.

Daunton, Martin. Just Taxes: The Politics of Taxation in Britain, 1914-1979. Cambridge: Cambridge University Press, 2007.

Ebrahimi, Mansoureh. The British Role in Iranian Domestic Politics (1951-1953). Springer Briefs in Environment, Security, Development and Peace, Vol. 5. UT Malaysia, Springer, 2016.

Eden, Lorraine, Stefanie Lenway and Douglas Schuler. “From the Obsolescing Bargain to the Political Bargaining Model." Bush School Working Paper (2004), No. 403.

Esfahani, Hadi and Mohammad Pesaran. "Iranian Economy in the Twentieth Century: A Global Perspective." Cambridge Working Papers in Economics 0815, Faculty of Economics: University of Cambridge: (2008): 1-34.

Elm, Mostafa. Oil, Power, and Principle: Iran's Oil Nationalisation and its Aftermath. Syracuse, NY: Syracuse University Press, 1992.

Farge, Nathan, and Louis Wells. "Bargaining Power of the Multinationals and Host Governments." Journal of International Business Studies 13, no. 2 (1982): 9-24.

Ferrier, Ronald. "The Anglo Iranian Oil Dispute: A Triangular Relationship." In Musaddiq, Iranian Nationalism and Oil, edited by J.A. Bill and W.R. Louis, 164-199, Austin: University of Texas Press.1988.

House of Commons. Parliamentary debates 1 (May 1951): 1011.

House of Commons. Parliamentary debates 21 (June 1951): 747.

Issawi, Charles, and Mohammed Yeganeh. The Economics of Middle Eastern Oil. New York, NY: Preager, 1962.

Johnson, Valerie. British Multinationals, Culture and Empire in the Early Twentieth Century. PhD Thesis: King's College, London, 2007. 
Jones, Geoffrey. "The Imperial Bank of Iran and Iranian Economic Development, 1890-1952." Business and Economic History, 2 d ser., 16 (1987): 69-80.

Keddie, Nikki. Modern Iran: Roots and Results of Revolution. London: Yale, 2006.

Kobrin, Stephen. "Diffusion as an Explanation of Oil Nationalisation." Journal of Conflict Resolution 29, no. 1 (1985): 3-32.

Kobrin, Stephen. "Testing the Bargaining Hypothesis in the Manufacturing Sector in Developing Countries." International Organization 4, no. 4 (1987): 609-638.

Kuniholm, Bruce Robellet. The Origins of the Cold War in the Near East: Great Power Conflict and Diplomacy in Iran, Turkey, and Greece. Princeton, NJ: Princeton University Press, 2014.

Levy, David, and Aseem Prakash. "Bargains Old and New: Multinational Corporations in Global Governance." Business and Politics 5, no. 2 (2003): 131-150.

Maltby, Josephine, and Matthew Tsamenyi. "Narrative Accounting Disclosure: Its Role in the Gold Mining Industry on the Gold Coast 1900-1949." Critical Perspectives on Accounting 21, no. 5 (2010): 390-401.

Mansoor, Moaddel. "State-centered Vs. Class-centered Perspectives on International Politics: The Case of U.S. and British Participation in the 1953 Coup Against Premier Mosaddeq in Iran." Studies in Comparative International Development 24, no. 2 (1989): 3-23.

Marsh, Steve. "HMG, AIOC and the Anglo-Iranian oil crisis." Diplomacy \& Statecraft 12, no. 4 (2001): 143-174.

Marsh, Steve. "Anglo-American Crude Diplomacy: Multinational Oil and the Iranian Oil Crisis, 19511953." Contemporary British History Journal 21, no. 1 (2007): 25-53.

Marsh, Steve. "The United States, Iran and Operation Ajax: Inverting Interpretative Orthodoxy." Middle Eastern Studies 39, no. 3 (2003): 1-38.

Neu, Dean, and Monica Heincke. "The Subaltern Speaks: Financial Relations and the Limits of Governmentality." Critical Perspectives on Accounting 15, no. 1 (2004): 179-206.

Nebus, James, and Carlos Rufin. "Extending the Bargaining Power Model: Explaining Bargaining Outcomes Among Nations, MNEs and NGOs." Journal of International Business Studies 41, no. 6 (2010): 996-1015.

Onslow, Sue. "Battlelines for Suez: The Abadan Crisis of 1951 and the Formation of the Suez Group." Contemporary British History Journal 17, no. 2 (2003): 1-28.

Penrose, Edith. The Large International Firm in Developing Countries: The International Petroleum Industry. London: George Allen \& Unwin, 1968.

Sampson, Anthony. The Seven Sisters: The Great Oil Companies and the World They Made. London: Hodder and Stoughton, 1975.

Vachani, Sushil. “Enhancing the Obsolescing Bargain Theory: A Longitudinal Study of Foreign Ownership of US and European Multinationals."Journal of International Business Studies 26, no. 1 (1995): 159-180.

Vernon, Raymond. Sovereignty at Bay: The Multinational Spread of U.S. Enterprises. New York, NY, Basic Books, 1971.

Vernon, Raymond. "The Obsolescing Bargain: A Key Factor in Political Risk." In The International Essays for Business Decision Makers. vol. 5, edited by MB Winchester, 281-287. Houston, TX: Center for International Business, 1980.

Vivoda, Vlado. "Bargaining Model for the International Oil Industry." Griffith Asia Institute, Griffith University, Australia.

Vivoda, Vlado. "Resource Nationalism, Bargaining and International Oil Companies: Challenges and Change in the New Millennium." New Political Economy 14, no. 4 (2009): 517-534.

Yapp, Malcolm. British Documents on Foreign Affairs: Reports and Papers from Foreign Office Confidential Print, part IV, 1945-1950. Bethesda, MD: University Publications, 1999.

Yergin, Daniel. The Prize: The Epic Quest for Oil, Money, \& Power. New York, NY: Simon and Schuster, 1991. 